\title{
Pengaruh Kompetensi Terhadap Kinerja Arsiparis di Arsip Nasional Republik Indonesia (ANRI)
}

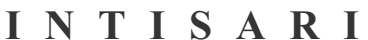

Kompetensi merupakan kriteria yang harus dimiliki oleh setiap pegawai yang melakukan pekerjaan dalam bidang tertentu, termasuk dalam bidang kearsipan. Kompetensi sangat dibutuhkan dalam membentuk sebuah kinerja yang baik demi mencapai tujuan organisasi atau perusahaan. Jika setiap pegawai memiliki kompetensi yang tinggi maka akan menghasilkan kinerja yang terbaik. Seorang arsiparis sebagai pengelola arsip dituntut untuk dapat memberikan berbagai informasi yang dibutuhkan oleh masyarakat. Seorang arsiparis harus memiliki tiga kompetensi dasar dibidang kearsipan yakni pengetahuan, keterampilan dan sikap. Penelitian ini bertujuan untuk mengetahui ada tidaknya pengaruh kompetensi arsiparis terhadap kinerja arsiparis di ANRI dan seberapa besar pengaruhnya serta juga mengidentifikasi indikator dari kompetensi yang memiliki pengaruh paling besar bagi arsiparis dalam melakukan kinerja. Berdasarkan hasil penelitian dapat diketahui secara menyeluruh kompetensi arsiparis yang terdiri dari indikator pengetahuan, keterampilan dan sikap memiliki pengaruh sebesar 56,4\% terhadap kinerja arsiparis di ANRI. Secara parsial konsep pengetahuan dan keterampilan tidak memiliki pengaruh yang signifikan dibandingkan dengan konsep sikap dengan thitung dari konsep pengetahuan sebesar 1,257 dan t hitung dari konsep keterampilan sebesar 1,141 sedangkan $\mathrm{t}$ hitung dari konsep sikap sebesar 5,535 dengan t tabel sebesar 1,991. Hal ini menunjukkan bahwa nilai $\mathrm{t}$ hitung dari konsep pengetahuan dan keterampilan lebih kecil dari t tabel sedangkan $\mathrm{t}$ hitung dari konsep sikap lebih besar dari $\mathrm{t}$ tabel, sehingga dapat disimpulkan bahwa konsep pengetahuan dan keterampilan tidak memiliki pengaruh yang signifikan dibandingkan dengan konsep sikap dalam melakukan kinerja arsiparis di ANRI.

\section{Farhan Bukhori, Laksmi}

Department of Library Science, Faculty of Humanities Universitas Indonesia, 16424 Depok, Indonesia farhan.bukhori@ui.ac.id 1lakasmi706@gmail.com

KATA KU N C I

Arsip Nasional Republik Indonesia, kinerja arsiparis, kompetensi arsiparis 


\section{$\begin{array}{llllllll}A & B & S & T & R & A & C & T\end{array}$}

Competence is a criterion that must be owned by every employee who does work in a particular field, including in the field of filing. Competence is needed in forming a good performance in order to achieve the goals of the organization or company. Because if every employee has high competence it will produce the best performance. As an archive manager, an archivist is required to be able to provide various information needed by the community. Therefore, an archivist must have three basic competencies in the field of filing, namely knowledge, skills and attitudes. This study aims to determine whether there is an influence of archivist competence on the performance of archivists at the National Archives of the Republic of Indonesia and how much they influence and also identify indicators of competencies that have the greatest influence on the archivists in performing performance. Based on the results of the study, it is known that overall archivist competency consisting of indicators of knowledge, skills and attitudes has an influence of $56.4 \%$ on the performance of archivists in the National Archives of the Republic of Indonesia. Partially the concept of knowledge and skills does not have a significant effect compared to the concept of attitude with t count from the concept of knowledge of 1.257 and $t$ count from the concept of skills of 1.141 while t count from the concept of attitude is 5.535 with t table of 1.991. This shows that the value of t count from the concept of knowledge and skills is smaller than $t$ table while $t$ count from the concept of attitude is greater than t table, so it can be concluded that the concepts of knowledge and skills do not have a significant effect compared to the concept of attitude in performing archivist performance at the National Archives of the Republic of Indonesia.
KEY WORDS

archivist competencies; archivist performance;

National Archives of Republic Indonesia

\section{PENGANTAR}

\section{Latar Belakang Masalah}

Kompetensi merupakan kemampuan yang harus dimiliki oleh setiap pegawai yang bekerja pada suatu bidang tertentu dengan tujuan agar hasil kerja dari setiap pegawai dapat sesuai bahkan melebihi dari ekspektasi yang diharapkan oleh perusahaan. Berbagai lembaga organisasi telah menentukan kompetensi minimum yang harus dimiliki oleh setiap pegawainya untuk menjalankan tugas dan fungsi dari masing-masing pegawai demi mencapai tujuan lembaga organisasi. 
Setiap pekerjaan memiliki kompetensinya tersendiri dan tentu saja hal ini membuat perbedaan kompetensi yang harus dimiliki oleh setiap pegawai untuk menempati berbagai posisi yang telah ditetapkan.

Kompetensi dari setiap pegawai tentu saja akan berpengaruh terhadap kinerja sekaligus hasil dari sebuah pekerjaan, karena sebuah pekerjaan jika dilakukan bukan oleh ahlinya (yakni tidak memenuhi kompetensi dari suatu pekerjaan) maka hasil yang akan diperoleh juga tidak akan baik. Penempatan posisi yang tidak sesuai dengan kompetensi yang dimiliki oleh tiap pegawai akan merugikan organisasi dalam mencapai tujuan serta menghambat organisasi dalam melakukan berbagai aktivitas sehari-hari.

Spencer dan Spencer (1993) dalam Calista (2016:45) menyebutkan kompetensi merupakan karakteristik mendasar yang harus dimiliki oleh seseorang dalam berperilaku atau berpikir, menyamakan situasi dan mendukung untuk periode waktu cukup lama. Setiap pegawai diharuskan memiliki kemampuan dan kompetensi yang diperlukan untuk menjalankan sebuah pekerjaan secara baik dan benar demi mendapatkan hasil yang diharapkan serta tercapainya tujuan organisasi.
Secara umum tujuan dari sebuah organisasi akan dapat terwujud manakala sebuah pekerjaan dilakukan oleh pegawai yang memiliki kompetensi dan kinerja yang baik. Begitupun sebaliknya apabila sebuah pekerjaan dilakukan tidak sesuai dengan kompetensi dan kinerja yang ditetapkan maka organisasi tersebut akan mengalami hambatan dan kesulitan untuk mencapai tujuan yang ingin dicapai dari sebuah organisasi.

Tingkat keberhasilan sebuah organisasi tidak lepas dari kinerja individu masing-masing pegawainya, karena kinerja pegawai dapat mempengaruhi kinerja tim kerja yang pada akhirnya juga akan memepengaruhi kinerja organisasi secara keseluruhan. Kinerja individu itu sendiri merupakan hasil yang dicapai oleh setiap pegawai dalam menjalankan pekerjaannya. Peningkatan kinerja pegawai akan mempengaruhi meningkatnya performa dari organisasi dalam memenangkan persaingan hingga akhirnya tujuan dari organisasi tersebut dapat terpenuhi.

Mangkunegara (2011: 67) mengungkapkan bahwa kinerja merupakan hasil kerja secara kualitas dan kuantitas yang dicapai oleh seorang pegawai dalam melaksanakan tugasnya sesuai dengan tanggung jawab 
yang diberikan kepadanya. Dengan demikian kinerja dari setiap pegawai sangat menentukan tingkat keberhasilan dalam mencapai tujuan lembaga organisasi, termasuk organisasi kearsipan. Keberadaan arsip tidak hanya sekedar pendukung kegiatan opersional suatu organisasi melainkan juga sebagai bukti sejarah yang harus dijaga karena memiliki berbagai nilai yang terkandung dalam arsip tersebut seperti nilai hukum, edukasi, ekonomi dan juga nilai penelitian. Oleh karena itu arsip harus disimpan, dikelola dan dilestarikan keberadaannya agar dapat digunakan kembali ketika dibutuhkan secara cepat dan akurat.

ICA atau International Council

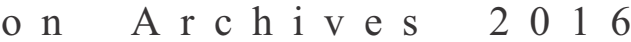
(https://www.ica.org/en/whatarchive) menyebutkan arsip merupakan informasi terekam sebagai hasil dari kegiatan manusia yang disimpan dalam jangka waktu tertentu dalam berbagai bentuk seperti teks, foto, video, suara, dan lain-lain. Selain itu Barthos (2009: 2) menyebutkan bahwa kearsipan mempunyai peranan sebagai pusat ingatan, sumber informasi dan alat pengawasan yang sangat diperlukan dalam setiap organisasi dalam rangka kegiatan perencanaan, penganalisaan, pengembangan, perumusan kebijaksanaan, pengambilan keputusan, pembuatan laporan, pertanggungjawaban, penilaian serta juga pengendalian setepat-tepatnya.

Pengelolaan arsip yang baik dan benar merupakan tugas seorang arsiparis atau petugas arsip dalam mengatur dan mengolah berbagai arsip agar arsip dapat ditemukan dan dimanfaatkan kembali untuk berbagai keperluan organisasi secara cepat dan tepat. Arsiparis harus memiliki pegetahuan dan keterampilan dalam mengatur dan mengurus berbagai kegiatan yang berkaitan dengan arsip demi memudahkan penemu kembalian arsip, selain itu seorang arsiparis seharusnya juga memiliki sikap yang baik agar dapat memberikan pelayanan secara maksimal kepada setiap masyarakat pengguna arsip.

Menurut Richard J. Cox (1992) dalam Siambaton (2017: 247) arsiparis adalah orang yang terdidik secara profesional, terlatih dan berpengalaman, dan bertanggung jawab dalam pengelolaan atau administrasi arsip dengan melakukan kegiatan penilaian dan mengidentifikasi arsip yang memiliki n i 1 a i b e r k e 1 a n j u t a n, mendokumentasikan dan melestarikan arsip sesuai dengan k e pe ntingannya de ngan 
mengupayakan serta menfasilitasi $\mathrm{p}$ e $\mathrm{ng} \mathrm{g} u \mathrm{n}$ a a n y a s e c a r a berkesinambungan.

ANRI merupakan salah satu lembaga kearsipan yang mengelola serta memelihara khasanah arsip yang ada di Indonesia pada masa kolonialisme hingga Indonesia merdeka. Sebagai lembaga pemerintahan nondepartemen setiap pegawai yang terdapat di ANRI merupakan aparatur sipil negara atau pegawai negeri sipil yang terikat dengan negara, untuk itu ANRI sangat terbuka dalam menentukan dan mengangkat setiap pegawainya atau dengan kata lain ANRI memberikan kebebasan dan kesempatan bagi setiap masyarakat untuk dapat bergabung menjadi arsiparis di ANRI dengan berbagai kriteria dan persyaratan. Siapapun dapat menjadi arsiparis tanpa melihat latar belakang pendidikan yang telah ditempuh sebelumnya.

Dengan demikian, jelas bahwa arsiparis memiliki nilai dan fungsi yang sangat penting dalam menjaga dan memelihara arsip sebagai khasanah kekayaan nasional, selain itu arsiparis juga dituntut untuk memiliki kompetensi, keahlian dan wawasan dalam mengelola berbagai khasanah arsip. Peneliti tertarik untuk melakukan penelitian terkait arsiparis atau tenaga pengelola arsip di ANRI dengan judul "Pengaruh Kompetensi terhadap Kinerja Arsiparis di ANRI". Rumusan Masalah

Berdasarkan gambaran latar belakang, seorang arsiparis dituntut untuk memiliki kompetensi dalam menangani dan mengelola berbagai arsip yang dimiliki. Maka dari itu penulis merumuskan pertanyaan penelitian agar hasil penelitian lebih terarah yakni "Apakah ada pengaruh antara kompetensi arsiparis terhadap kinerja arsiparis di ANRI dan seberapa besar pengaruhnya?"

Tujuan dan Manfaat Penelitian

Berdasarkan pertanyaan penelitian tersebut maka tujuan dari penelitian ini adalah:

1. Untuk mengetahui ada tidaknya pengaruh kompetensi arsiparis terhadap kinerja arsiparis di ANRI dan seberapa besar pengaruhnya.

2. Untuk mengidentifikasi kompetensi yang memiliki pengaruh paling besar bagi arsiparis dalam melakukan kinerja di ANRI.

Selain itu penelitian ini diharapkan dapat memberikan manfaat baik bagi peneliti maupun bagi praktisi dalam bidang kearsipan, diantaranya adalah:

1. ManfaatAkademis

Hasil penelitian ini diharapkan 
dapat memberikan kontribusi bagi sivitas akademisi dalam menambah khasanah penelitian khususnya yang berkaitan dengan kompetensi arsiparis, serta sebagai rujukan dalam mengembangkan penelitian yang lebih luas dan mendalam untuk penelitian selanjutnya.

2. Manfaat praktis

Manfaat praktis dari penelitian ini diharapkan dapat memberikan pemahaman serta mendorong arsiparis untuk meningkatkan kompetensi yang dimiliki agar menghasilkan kinerja terbaik khususnya bagi arsiparis maupun perencana arsip di ANRI dalam mengelola dan meningkatkan kemampuan dalam bidang kearsipan.

\section{Metodologi Penelitian}

Jenis penelitian ini merupakan penelitian lapangan (field research) yang digunakan untuk memperoleh data primer dengan melakukan pengamatan secara langsung serta penyebaran kuesioner terhadap objek yang diteliti. Pendekatan yang digunakan adalah pendekatan kuantitatif menggunakan metode survei yakni untuk mengetahui dan mengukur besaran tingkat kompetensi arsiparis terhadap kinerja arsiparis di
ANRI. Menurut Sugiyono (2015: 8) penelitian kuantitatif adalah metode penelitian yang berlandaskan pada filsafat positivisme yang digunakan untuk meneliti pada populasi atau sampel tertentu dengan teknik pengambilan sampel secara random dan pengumpulan data menggunakan instrumen penelitian, analisis data bersifat kuantitatif/ statistik dengan tujuan untuk menguji hipotesis.

Variabel dalam penelitian terdiri dari variabel independen atau variabel bebas yakni kompetensi arsiparis dan variabel dependen atau variabel terikat yakni kinerja arsiparis. Populasi dalam penelitian ini adalah seluruh arsiparis yang bertugas dalam bidang konservasi arsip di ANRI yang berjumlah 120 (seratus dua puluh) orang dengan sampel yang digunakan sebanyak 92 (sembilan puluh dua) orang dengan margin of error sebesar $5 \%$. Teknik pengumpulan data dalam penelitian ini adalah penyebaran kuesioner dan observasi dengan teknik analisis data yang digunakan adalah uji normalitas dan uji linieritas, analisis regresi linier serta uji t dan uji koefisien determinasi dengan menggunakan SPSS 24. 
Kerangka Pemikiran

Mengingat peran arsip yang sangat penting bagi sebuah organisasi maka dalam penelitian ini dibuat kerangka berpikir untuk memudahkan dalam memahami pengaruh kompetensi arsiparis terhadap kinerja arsiparis. Penelitian ini menggunakan konsep kompetensi menurut Peraturan Kepala Arsip Nasional RI (PERKA ANRI) Nomor 6 Tahun 2016 dan konsep kinerja menurut Setiawan dan Dewi (2014: 1477) dengan uraian sebagai berikut: sesuai kualifikasi jabatannya. Martinez dan Whatley (2011:77) mengungkapkan bahwa kompetensi arsiparis adalah perpaduan dari pengetahuan, keterampilan dan sikap yang dibutuhkan oleh seorang arsiparis untuk mencapai tingkat kinerja profesional yang diakui.

Cahyaningrat, Erviantono dan Wismayanti (2017:46) menyebutkan bahwa kompetensi akan membentuk suatu karakter kerja pegawai dengan terbentuknya hasil kerja yang baik dan memuaskan, maka instansi pemerintahan ataupun swasta

\begin{tabular}{l}
\hline Kompetensi Arsiparis \\
\begin{tabular}{l} 
- Pengetahuan \\
- Keterampilan \\
- Sikap \\
\hline
\end{tabular}
\end{tabular}

\section{Gambar 1}

Kerangka Berpikir

Sumber Gambar: Data Primer, 2019

\section{Tinjauan Literatur}

\section{Kompetensi}

Menurut PERKA ANRI

Nomor 6 Tahun 2016 tentang Pedoman Sertifikasi Jabatan Fungsional Arsiparis, kompetensi arsiparis adalah rumusan kemampuan kerja di bidang kearsipan yang mencakup aspek pengetahuan, keterampilan dan atau keahlian, sikap kerja yang minimal harus dimiliki arsiparis dengan melaksanakan tugas menegaskan perlunya kompetensi dalam organisasi. Selain itu Alan Aspey dalam Dewiyana (2011:24) menekankan bahwa pengertian kompetensi tidak hanya meliputi penguasaan keterampilan dan pengetahuan saja, tetapi juga termasuk penguasaan terhadap tugas dan motivasi dalam menjalankan tugas tersebut.

Berdasarkan pengertian di atas kompetensi arsiparis merupakan 
pengetahuan, keterampilan serta juga sikap yang harus dimiliki oleh seorang arsiparis dalam bekerja atau menjalankan tugas kearsipan sesuai dengan jabatan yang dimiliki. Suliman Al-Hawandeh dan S. Foo (2001) dalam Dewiyana $(2011: 26)$ menyebutkan enam kategori kompetensi yang harus dimiliki oleh seorang profesional di bidang informasi pada era informasi, yaitu:

a. Keterampilan teknologi;

b. Keterampilan informasi;

c. Keterampilan komunikasi social;

d. Keterampilan manajemen dan kepemimpinan;

e. Keterampilan berpikir strategis dan analitis dan

f. Perilaku dan sifat-sifat yang bersifat pribadi.

PERKA ANRI Nomor 6 Tahun 2016 tentang Pedoman Sertifikasi Jabatan Fungsional Arsiparis menyebutkan bahwa kompetensi yang harus dimiliki oleh seorang arsiparis adalah sebagai berikut:

a. Pengetahuan

Aspek pengetahuan merupakan kompetensi dasar yang harus dimiliki oleh seorang arsiparis dalam melakukan kegiatan kearsipan yang tidak hanya meliputi pengetahuan tentang pengelolaan arsip saja tapi juga keilmuan lainnya seperti sejarah, budaya, informasi dan teknologi, ekonomi serta ilmu lainnya yang mendukung tugas arsiparis.

b. Keterampilan

Seorang arsiparis juga harus memiliki keterampilan dalam melekaukan pengelolaan, menempatakan, menemukan kembali arsip, dan memilah golongan arsip serta arsiparis juga harus memiliki keterampilan dalam menggunakan sarana prasaran sehingga dapat menyajikannya secara cepat dan tepat sesuai dengan kebutuhan.

c. Sikap

Selain pengetahuan dan keterampilan seorang arsiparis dituntut untuk memiliki sikap profesional yakni sabar, teliti, mandiri, bertanggung jawab serta memiliki peran aktif dalam menjalankan tugas kearsipan.

Perkembangan teknologi yang semakin pesat juga menyebabkan perubahan pada media penyimpanan arsip. Hal ini mengakibatkan arsiparis untuk memiliki kemampuan dan keahlian menggunakan teknologi dalam mengelola arsip yang dimiliki sesuai dengan perkembangan teknologi. Oleh karena itu, perlu diadakan pengembangan kompetensi arsiparis agar arsiparis selalu siap dalam mengelola arsip pada masa 
sekarang dan yang akan datang.

Menurut Handayani dan Sari (2018:228) terdapat beberapa faktor yang menyebabkan arsiparis Indonesia belum memiliki sikap profesionalisme dalam bidang kearsipan, yaitu:

a. Strategi pembangunan Nasional yang cenderung berorientasi pada hal-hal yang bersifat material;

b. Rendahnya budaya membaca;

c. Rendahnya apresiasi terhadap bidang kearsipan dan

d. Kuatnya feodalisme dalam kehidupan sosial.

$\mathrm{Handayani}$ dan Sari (2018:228) mengungkapkan cara yang $\mathrm{d} a \mathrm{pat} \mathrm{di} 1 \mathrm{akukan} \mathrm{da} \mathrm{km}$ mengembangkan kompetensi arsiparis, yaitu: (a) Menambah pengetahuan pegawai; (b) Meningkatkan pengabdian, mutu, keahlian dan keterampilan pegawai. (c) Mengubah dan membentuk sikap pegawai; dan (d) Mengembangkan keahlian pegawai sehingga pekerjaan dapat dikelola dengan mudah dan baik.

\section{Kinerja}

Mangkunegara (2011:67) menyebutkan kinerja sebagai hasil kerja secara kualitas dan kuantitas yang dicapai oleh seorang karyawan dalam melaksanakan tugasnya sesuai dengan tanggung jawab yang diberikan kepadanya. Selain itu Moeheriono dalam Makawi (2015:19) juga menyebutkan bahwa kinerja merupakan suatu hasil kerja yang dicapai oleh seseorang atau sekelompok orang dalam suatu organisasi, baik secara kuantitatif maupun kualitatif sesuai dengan wewenang dan tugas tanggung jawabnya masing-masing untuk mencapai tujuan organisasi bersangkutan secara legal (tidak melanggar hukum) dan sesuai dengan moral maupun etika.

Berdasarkan pengertian di atas terkait kinerja karyawan dapat disimpulkan bahwa kinerja adalah hasil dari sebuah pekerjaan yang telah dicapai oleh seseorang baik kuantitas maupun kualitas yang diberikan kepadanya sesuai dengan kemampuan yang dimiliki dan kriteria atau standar minimum dari pekerjaan tersebut. Calista (2016: 46) mengungkapkan bahwa karyawan yang memiliki kinerja yang baik adalah karyawan yang memiliki kualitas kerja yang baik, kuantitas kerja yang besar, sikap baik atau ramah, dapat diandalkan, berinisiatif, rajin, selalu hadir dalam bekerja dan memiliki potensi untuk maju.

Menurut Setiawan dan Dewi (2014: 1477) untuk mengukur sebuah kinerja dapat menggunakan konsep 
sebagai berikut:

a. Ketepatan penyelesaian tugas merupakan pengelolaan waktu dalam bekerja dan juga ketepatan karyawan dalam menyelesaikan pekerjaan;

b. Kesesuaian jam kerja merupakan kesediaan karyawan dalam mematuhi peraturan perusahaan yang berkaitan dengan ketepatan waktu masuk atau pulang kerja serta jumlah kehadiran;

c. Jumlah ketidak hadiran karyawan dalam suatu perusahaan selama periode tertentu dan

d. Kerjasama antar karyawan merupakan kemampuan karyawan untuk bekereja sama dengan orang lain dalam menyelesaikan suatu tugas yang ditentukan sehingga mencapai daya guna dan hasil guna yang sebesar-besarnya.

\section{Arsiparis}

Secara sederhana ARMA (Associations of Records Managers and Administrators) mendefinisikan arsiparis sebagai seorang profesional yang bertugas melakukan administrasi arsip dan atau manajemen kearsipan (Franks, 2013:342). Menurut Undangundang Nomor 43 Tahun 2009 tentang Kearsipan, pasal 1 ayat 10 menerangkan arsiparis sebagai seseorang yang memiliki kompetensi di bidang kearsipan yang diperoleh melalui pendidikan formal dan/ pendidikan dan pelatihan kearsipan serta mempunyai fungsi, tugas, dan tanggung jawab melaksanakan kegiatan kearsipan.

Siambaton (2017:248) menyebutkan empat kriteria profesionalisme yang harus dimiliki oleh seorang arsiparis, yaitu:

a. Memiliki kemampuan teknis dan keilmuan yang menjamin efisiensi perawatan, pengamanan dan pelayanan informasi pada instansi dan pelestarian budaya bangsa selektif dan selengkap mungkin;

b. Memahami suatu sistem adminsitrasi secara baik dan memiliki kemampuan untuk mengembangkan suatu sistem kearsipan dan mengelola informasi arsip untuk berbagai kepentingan dalam rangka pelayanan administrasi, praktisi, keilmuan dan umum tanpa mengorbankan kepentingan lain yang karena ketentuan perundangundangan atau etika harus memperoleh perlindungan;

c. Memahami dengan baik prinsi-prinsip kearsipan praktis dan mampu menjabarkan konsepkonsep dan teori-teori kearsipan dan menterjemahkannya dalam praktik kegiatan kearsipan dan 
d. Memiliki kemampuan untuk melakukan pengkajian terhadap teori/ konsep kearsipan, melaksanakan penelitian dan merumuskan alternatif baru di bidang kearsipan.

\section{PEMBAHASAN}

\section{Analisis Data}

Berikut merupakan hasil analisis data yang digunakan dalam penelitian ini untuk mengetahui pengaruh kompetensi arsiparis terhadap kinerja arsiparis yaitu uji normalitas dan uji linieritas, analisis regresi linier, uji t dan uji koefisien determinasi.

Uji Normalitas dan Uji Linieritas Uji normalitas digunakan untuk menguji tingkat normalitas sebuah model regresi dalam distribusi data, karena model regresi yang baik adalah berdistribusi normal atau mendekati normal. Berikut merupakan hasil uji normalitas yang telah dilakukan menggunakan SPSS 24.

Tabel 1

Hasil Uji Normalitas

\begin{tabular}{|l|l|r|}
\hline \multicolumn{2}{|l|}{} & $\begin{array}{c}\text { Unstandardized } \\
\text { Residual }\end{array}$ \\
\hline N & 92 \\
\hline Normal Parameters & Mean & .0000000 \\
\cline { 2 - 3 } & $\begin{array}{l}\text { Std. } \\
\text { Deviation }\end{array}$ & 5.35982907 \\
\hline $\begin{array}{l}\text { Most Extreme } \\
\text { Differences }\end{array}$ & Absolute & .053 \\
\cline { 2 - 3 } & Positive & .053 \\
\cline { 2 - 3 } & Negative & -.047 \\
\hline Test Statistic & & .053 \\
\hline Asymp. Sig. (2-tailed) & & $.200^{\mathrm{c}, \mathrm{d}}$ \\
\hline
\end{tabular}

Sumber: Data Primer, 2019. 
Berdasarkan tabel 1 (satu) mengenai hasil uji normalitas diketahui nilai signifikansi sebesar 0,200. Hal ini menunjukkan bahwa nilai signifikansi yang diperoleh lebih besar dari 0,05 atau $0,200>0,05$ dengan demikian dapat disimpulkan bahwa distribusi variabel independen atau kompetensi arsiparis memiliki persebaran data normal dengan nilai signifikansi lebih dari 0,05.
Selain uji normalitas digunakan pula uji linieritas dengan tujuan untuk mengetahui arah hubungan dari variabel independen atau kompetensi arsiparis terhadap variabel dependen atau kinerja arsiparis, apakah memiliki hubungan yang linier (segaris) atau tidak. Berikut ini merupakan hasil uji linieritas yang telah dilakukan menggunakan SPSS 24.

Tabel 2

Hasil Uji Linieritas

\begin{tabular}{|c|c|c|c|c|c|c|c|}
\hline & & & $\begin{array}{l}\text { Sum of } \\
\text { Squares }\end{array}$ & Df & $\begin{array}{l}\text { Mean } \\
\text { Square }\end{array}$ & $\mathrm{F}$ & Sig. \\
\hline \multirow{5}{*}{$\begin{array}{l}\text { Kinerja * } \\
\text { Kompetensi }\end{array}$} & \multirow{3}{*}{$\begin{array}{l}\text { Between } \\
\text { Groups }\end{array}$} & (Combined) & 3825.686 & 34 & 112.520 & 3.344 & .000 \\
\hline & & Linearity & 3129.632 & 1 & 3129.632 & $\begin{array}{r}92.99 \\
9\end{array}$ & .000 \\
\hline & & $\begin{array}{l}\text { Deviation } \\
\text { from } \\
\text { Linearity }\end{array}$ & 696.055 & 33 & 21.093 & .627 & .925 \\
\hline & \multicolumn{2}{|c|}{ Within Groups } & 1918.172 & 57 & 33.652 & & \\
\hline & \multicolumn{2}{|l|}{ Total } & 5743.859 & 91 & & & \\
\hline
\end{tabular}

Sumber: Data Primer, 2019.

Berdasarkan tabel 2 (dua) mengenai hasil uji linieritas diketahui nilai signifikansi deviation from linearity sebesar 0,925. Hal ini menunjukkan bahwa niliai signifikansi yang diperoleh lebih besar dari 0,05 maka dapat disimpulkan bahwa terdapat hubungan yang linier antara kompetensi dan kinerja.

\section{Analisis Regresi Linier}

Analisis regresi linier adalah analisis yang dilakukan untuk mengetahui pengaruh variabel independen (kompetensi arsiparis) terhadap variabel dependen (kinerja arsipris) serta juga untuk mengetahui arah hubungannya. Berikut merupakan hasil analisis dari regresi linier. 
Tabel 3

Hasil Uji Regresi Linier

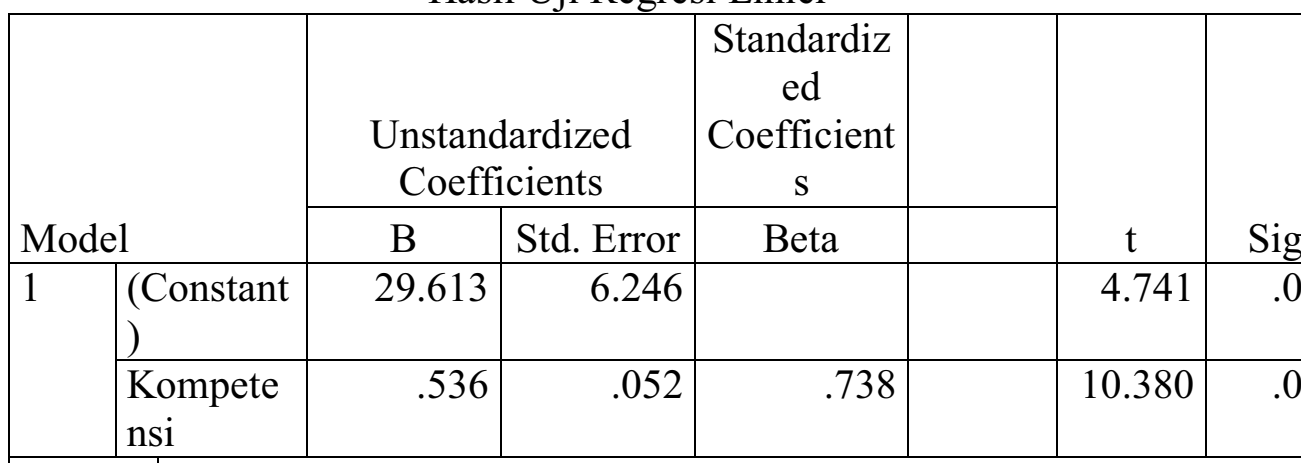

a. Dependent Variable: Kinerja

Sumber: Data Primer, 2019.

Berdasarkan tabel 3 (tiga) mengenai hasil uji regresi linier diperoleh nilai signifikansi sebesar 0,000. Hal ini mengindikasikan bahwa terdapat pengaruh antara kompetensi arsiparis terhadap kinerja arsiparis dengan ketentuan jika nilai signifikansi yang diperoleh kurang dari 0,05 maka memiliki pengaruh.

\section{Uji T dan Uji Koefisien Determinasi}

Uji t digunakan untuk mengetahui besarnya pengaruh variabel independen (kompetensi arsiparis) secara sendiri-sendiri berdasarkan konsep pembentuk dari kompetensi arsiparis. Indikator pembentuk kompetensi arsiparis diantaranya adalah pengetahuan, keterampilan dan sikap. Berikut merupakan hasil dari uji t.

Tabel 4

Hasil Uji T

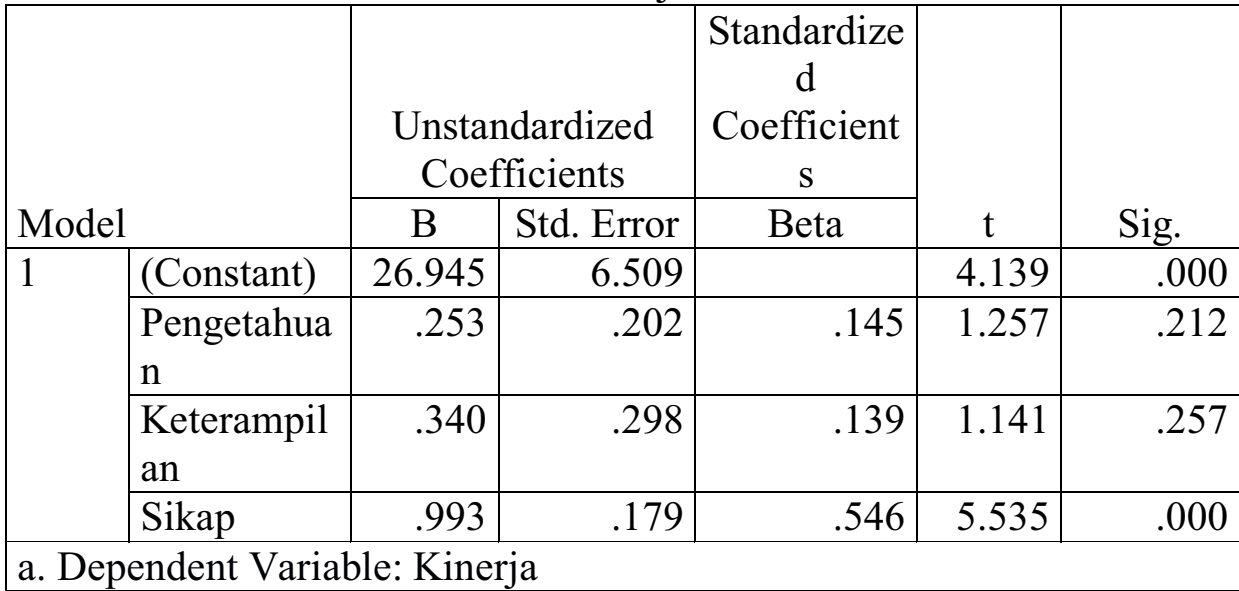

Sumber: Data Primer, 2019. 
Berdasarkan tabel 4 (empat) mengenai hasil uji t menunjukkan bahwa indikator pengetahuan memperoleh nilai t hitung sebesar 1,257 dengan nilai signifikansi 0,212 dan indikator keterampilan memperoleh $\mathrm{t}$ hitung sebesar 1,141 dengan nilai signifiknasi 0,257 sedangkan indikator sikap memperoleh $\mathrm{t}$ hitung sebesar 5,535 dengan signifikansi 0,000 . Hal ini menunjukkan bahwa indikator pengetahuan dan indikator keterampilan tidak memiliki pengaruh signifikan terhadap kinerja karena nilai $\mathrm{t}$ hitung yang diperoleh lebih kecil dari nilai t tabel sebesar 1,991 yakni 1,257 dan 1,141 sedangkan indikator sikap memiliki pengaruh terhadap kinerja dengan nilai t hitung yang dimiliki lebih besar dari pada nilai t tabel yakni sebesar 5,535.

Pengujian koefisien determinasi ditujukan untuk mengetahui besarnya pengaruh kompetensi arsiparis terhadap kinerja arsiparis. Berikut merupakan hasil dari pengujian koefisien determinasi:

Tabel 5

Hasil Uji Koefisien Determinasi

\begin{tabular}{|l|r|r|r|r|}
\hline Model & R & R Square & $\begin{array}{c}\text { Adjusted R } \\
\text { Square }\end{array}$ & $\begin{array}{c}\text { Std. Error of } \\
\text { the Estimate }\end{array}$ \\
\hline 1 & $.760^{\mathrm{a}}$ & .578 & .564 & 5.24655 \\
\hline
\end{tabular}

Sumber: Data Primer, 2019.

Tabel 5 (lima) mengenai hasil uji koefisien determinasi diperoleh nilai 0,564 . Hal ini menunjukkan bahwa pengaruh kompetensi terhadap kinerja arsiparis sebesar 56,4\% sedangkan sisanya 43,6\% dipengaruhi oleh faktor lain di luar indikator pengetahuan, keterampilan dan sikap "Pengaruh Kompetensi Arsiparis terhadap Kinerja Arsiparis".

Berdasarkan hasil analisis data yang telah dilakukan diketahui bahwa kompetensi arsiparis memiliki pengaruh terhadap kinerja arsiparis ANRI. Hal ini dibuktikan melalui hasil uji regresi linier yang memperoleh nilai signifikansi sebesar 0,000 yang menunjukkan bahwa nilai yang diperoleh lebih kecil dari 0,005. Kompetensi yang baik dapat membentuk suatu karakter kerja pegawai yang akhirnya akan menjadi kinerja yang baik juga (Cahyaningrat, 2017:46).

Kompetensi arsiparis tidak dapat berdiri sendiri tanpa adanya 
konsep pembentuk kompetensi. Konsep pembentuk kompetensi arsiparis yaitu pengetahuan, keterampilan dan sikap dari para arsiparis. Berdasarkan hasil uji t yakni pengujian yang dilakukan untuk mengetahui arah pengaruh dari setiap konsep pembentuk kompetensi atau dengan kata lain pengujian yang dilakukan secara tersendiri terhadap masing-masing konsep dengan ketentuan apabila nilai t hitung yang diperoleh lebih besar dari t tabel maka konsep tersebut memiliki pengaruh terhadap kinerja dengan $t$ tabel dalam penelitian ini sebesar 1,991.

Faktor pertama yang mempengaruhi kinerja pegawai adalah pengetahuan, karena dengan pengetahuan yang dimiliki setiap pegawai membuat hasil kerja menjadi lebih baik serta membantu pegawai dalam menyelesaikan berbagai permasalahan. Pengetahuan yang harus dimiliki oleh seorang arsiparis bukan hanya sekedar pengetahun mengenai administrasi atau pengolahan arsip saja, melainkan juga pengetahuan bidang lain terkait arsip seperti bidang sosial, sejarah, budaya, teknologi serta berbagai bidang lainnya. Hasil analisis uji t diketahui nilai thitung dari konsep pengetahuan sebesar 1,257 skor ini menunjukkan bahwa nilai t hitung yang diperoleh lebih kecil dari t tabel yang berarti bahwa konsep pengetahuan tidak memiliki pengaruh yang signifikan terhadap kinerja arsiparis.

Faktor yang mempengaruhi kinerja selanjutnya adalah keterampilan. Keterampilan yang dimiliki oleh setiap pegawai memudahkan pegawai itu sendiri dalam melakukan berbagai aktivitas terkait pekerjaan yang ditekuni secara cepat dan tepat. Keterampilan yang harus dimiliki oleh seorang arsiparis dalam mengelola arsip diantaranya adalah keterampilan dalam menentukan arsip berdasarkan jenisnya, keterampilan dalam menemu kembalikan arsip yang dibutuhkan secara cepat dan tepat serta juga keterampilan dalam menggunakan sarana prasarana penunjang. Hasil analisis uji t yang dilakukan terhadap konsep keterampilan diketahui nilai t hitung sebesar 1,141 yang menunjukkan bahwa nilai t hitung yang diperoleh lebih kecil dari t tabel. Hal ini dapat diartikan bahwa konsep keterampilan juga tidak terlalu memiliki pengaruh yang signifikan terhadap kinerja.

Faktor yang mempengaruhi kinerja yang terakhir adalah sikap. Sikap merupakan perilaku atau tindakan yang menjadi karakter setiap pegawai dalam melakukan pekerjaan 
dan berinteraksi dengan sesama pegawai. Selain itu semua pegawai dituntut untuk melakukan sikap profesional dalam bekerja untuk mencapai hasil kerja yang baik dan memuaskan. Berdasarkan hasil analisis uji t mengenai konsep sikap diperoleh nilai t hitung sebesar 5,535 yang menunjukkan bahwa nilai $t$ hitung lebih besar dari t tabel sehingga dapat dikatakan bahwa kompetensi dari konsep sikap memiliki hubugan yang signifikan terhadap kinerja arsiparis di ANRI. Konsep sikap ini terdiri dari sikap responden yang meliputi kesabaran, ketelitian, tanggung jawab, tolong menolong dan berperan aktif dalam menjalankan tugas kearsipan. Hal ini sesuai dengan pendapat McAshan (1981) dalam Sutrisno (2011:203) bahwa kompetensi yang dimiliki oleh seorang pegawai merupakan bagian dari dirinya sehingga ia dapat melakukan perilaku kognitif sebagai hasil kinerja yang baik.

Selain itu kompetensi arsiparis yang terdiri dari konsep pengetahuan, keterampilan dan sikap memiliki pengaruh sebesar 56,4\% terhadap kinerja arsiparis di ANRI sedangkan sisanya yakni 43,6\% dipengaruhi oleh faktor lain di luar konsep yang telah dibahas dalam penelitian ini yakni konsep pengetahuan, keterampilan dan sikap. Dengan demikian, diharapkan untuk penelitian selanjutnya dapat mengungkapkan faktor lain di luar konsep yang telah di bahas dalam penelitian ini.

\section{KESIMPULAN}

Berdasarkan hasil penelitian dan analisis data yang telah dilakukan dapat disimpulkan bahwa secara keseluruhan kompetensi arsiparis yang terdiri dari pengetahuan, keterampilan dan sikap mempengaruhi kinerja arsiparis di ANRI sebesar $56,4 \%$ dalam menjalankan aktivitasnya sehari-hari. Selain itu dari hasil analisis secara parsial diketahui nilai $\mathrm{t}$ hitung dari indikator pengetahuan sebesar 1,257 dan $\mathrm{t}$ hitung indikator keterampilan sebesar 1,141 dengan t tabel sebesar 1,991. Hal ini menunjukkan bahwa nilai t hitung pengetahuan dan keterampilan lebih kecil dari t tabel.

Dengan demikian dapat disimpulkan bahwa secara keseluruhan konsep pengetahuan dan keterampilan bernilai baik namun tidak dapat mepengaruhi kinerja arsiparis di ANRI. Untuk mencapai hasil kerja yang baik dan memuaskan membutuhkan beberapa keahlian dan keterampilan seperti keterampilan komunikasi dan informasi serta keahlian dalam menggunakan 
teknologi dan sarana pendukung.

Berbeda dari dua konsep sebelumnya, konsep sikap memiliki pengaruh signifikan terhadap kinerja arsiparis di ANRI dibandingkan dengan konsep pengetahuan dan konsep keterampilan. Hal ini dapat dilihat dari hasil uji t yang memperoleh nilai $\mathrm{t}$ hitung sebesar 5,535 menunjukkan bahwa nilai $\mathrm{t}$ hitung lebih besar dari t tabel. Dengan demikian, konsep sikap memiliki pengaruh yang signifikan terhadap kinerja arsiparis di ANRI dibandingkan dengan konsep pengetahuan dan konsep keterampilan. Konsep sikap ini meliputi kesabaran, ketelitian, tanggung jawab dan tolong menolong serta berperan aktif dalam melakukan inovasi dan penelitian dalam bidang kearsipan.

Mengingat pentingnya sebuah kompetensi yang harus dimiliki oleh arsiparis maka peneliti memberikan saran dan masukan sebagai berikut:

1. Memberikan pelatihan dan keterampilan kepada seluruh arsiparis khususnya arsiparis yang mengelola dan memberikan pelayanan arsip kepada pengguna;

2. Meningkatkan taraf pendidikan bagi setiap arsiparis agar semakin megetahui dan mengerti terkait dunia kearsipan sehingga dapat melakukan pengelolaan kearsipan dengan baik dan tepat sesuai kaidah kearsipan yang berlaku dan

3. Memilah dan memilih calon arsiparis pada penerimaan arsiparis yang akan datang sesuai dengan jenjang pendidikan/studi para calon arsiparis agar dapat melakukan pengelolaan kearsipan secara baik dan tepat karena telah memiliki pengetahuan dan pemahaman sebelumnya.

\section{DAFTAR PUSTAKA}

Barthos, Basir. 2009. Manajemen Kearsipan untuk Lembaga Negara, Swasta, dan Perguruan Tinggi. Bumi Aksara, Jakarta.

Franks, Patricia C. 2013. Records and Information Management. Shutterstock, Chicago.

Mangkunegara, A. A. 2011 . Manajeman Sumber Daya Manusia Perusahaan. Remaja Rosdakarya, Bandung.

Sugiyono. 2015. Metode Penelitian Kuantitatif, Kualitatif dan $R \& D$. Alfabeta, Bandung.

Sutrisno, Edy. 2011. Manajemen Sumber Daya Manusia. Kencana Prenada Media Grup, Jakarta.

Cahyaningrat, A.A Made Bintang., Erviantono, Tedi., \& Wismayanti, Kadek Wiwin Dwi. 2017. Pengaruh Kompetensi 
Terhadap Kinerja Pegawai di Badan Perpustakaan Arsip dan Dokumentasi Kota Denpasar. Jurnal Citizen Charter 1(1): 46-51.

Callista, Natasha. 2016. Pengaruh Kompetensi SDM terhadap Kinerja Karyawan Pada PT. Tresnamu Sejati Cabang Surabaya. Jurnal Agora 4(2): 45-50.

Dewiyana, Himma. 2011. Kompetensi d a n K u r i k u l u m Perpustakaan: Paradigma Barudan Dunia Kerja di Era Globalisasi Infirmasi. Jurnal Studi Perpustakaan dan Informasi 2(1): 22-31.

Setiawan, Ferry \& Dewi, Kartika. 2014. Pengaruh Kompensasi dan Lingkungan Kerja terhadap Kinerja Karyawan pada CV Berkat Anugrah. Jurnal Manajemen Universitas Udayana 3(5): 1471-1490.

Makawi, Umar. Normajatun \& Haliq, Abdul. 2015. Analisis Pengaruh Kompetensi terhadap Kinerja Pegawai Dinas Perindustrian dan $\mathrm{P}$ e r d a g a ng a $\mathrm{Kota}$ Banjarmasin. Jurnal AlUlum Ilmu Sosial dan Humaniora 1(1): 16-26.

International Council on Archives. 2016. What are Archives. https://www.ica.org/en/what -archive. Diakses 23 Mei 2019.

Martinez, Christine \& Whatley, Patricia. 2011. Shape Your
Own Archivist: the European Competency Template. Atlanti, No. 21.

Peraturan Kepala Arsip Nasional Republik Indonesia Nomor 6 tahun 2016 Pedoman Sertifikasi Jabatan Fungsional Arsiparis, 22 Januari 2016. Jakarta.

Undang-Undang Republik Indonesia Nomor 43 Tahun 2009 Kearsipan, 23 Oktober 2009. Lembaran Negara Republik Indonesia Tahun 2009 Nomor 152. Jakarta.

Siambaton, Ernita. 2017. Memahami Arsip dan Arsiparis dalam Manajemen Kearsipan di Amerika Serikat dan Indonesia. Industrial Research Workshop and National Seminar Bandung. 26-27 Juli. 245-249 